\title{
Myoglobin Measurement
}

National Cancer Institute

\section{Source}

National Cancer Institute. Myoglobin Measurement. NCI Thesaurus. Code C79436.

The determination of the amount of myoglobin present in a sample. 